\title{
Internationalizing American Higher Education: A Call to Thought and Action
}

\author{
Deborah DeZure \\ University of Michigan, Ann Arbor
}

In the wake of the World Trade Center disaster, many faculty developers are asking themselves what they do to promote international peace and understanding. But even before these events, there has been an indication that there was a pressing need to focus on global competencies as an important part of higher education for the 21st century. The purpose of this essay is threefold: 1) to summarize the research on the status of internationalization on American campuses, 2) to make the case for the active involvement of faculty developers in internationalizing higher education, and 3) to offer strategies with which we can begin or expand our efforts.

\section{INTRODUCTION}

Tn the wake of the World Trade Center disaster, many faculty developers are Lasking themselves what they can do in the context of their professional roles to promote international peace and understanding, beginning on their own campuses. But even before September 11, 2001, it was clear there was a pressing need to focus on global competencies as a critical feature of higher education for the 21 st century (Cornwell \& Stoddard, 1999; Hayward, 2000; Hayward \& Siaya, 2001; Institute of International Education, 2000). These reports on the status of internationalization in American higher education now take on even more urgency, deserving our attention and careful analysis. They offer insights into key areas that need our expertise and leadership. They can also help us to conceptualize and shape the role we can play in promoting internationalization and intercultural competencies. 
This is not a sea change for us. In the last decade, faculty developers across the United States understood and acted upon the need to promote diversity and multicultural competencies to support democratic pluralism, primarily in the context of American society. But we are now a world at war: It is clear that the stakes are very high, and the need is urgent to expand the diversity mandate to include global dimensions. The purpose of this essay is threefold: 1) to summarize the research on the status of internationalization on American campuses, 2) to make the case for the active involvement of faculty developers in internationalizing higher education as a natural extension of our ongoing work and commitments, and 3) to offer strategies with which we can begin or expand our efforts.

\section{Why ShOULD WE SUPPORT INTERNATIONALIZATION?}

Michael McPherson, President of Macalester College, sponsored a full page message in the New York Times titled, "International Education. Now More Than Ever" (2001, p. A30). It captures many of the reasons why internationalization is so critical for higher education:

Education remains the most important vehicle we have for promoting international understanding. We should be encouraging American students to learn all they can about the lives and histories of people around the world. We should encourage young people to study abroad-and not only in the more familiar territory of England and France, but in Eastern Europe, Asia, Africa and Latin America as well.

By the same token, we must keep the doors of American education open to students from all corners of the world.... I see first hand the growth both in understanding and curiosity about the world that happens for American students as they engage their collcagues from abroad. Meanwhile our international students experience not only a broad liberal arts experience... but they also acquire a deeper understanding of our complex, dynamic, and yet far from perfect country. Real education is the enemy of fanaticism and of complacency...

The events of September 11 have shattered forever the illusion, still cherished by too many Americans, that we stand at some distance from the world. We are, it must now be clear, for better and for worse, and quite inescapably, part of the world. However tempting it may be to try to withdraw into ourselves, our best-our only-hope is to engage the world in all its cultural and religious and human variation and to join in the struggle to improve it. (2001, p. A30) 
While the primary goal of McPherson's essay was to urge restraint in limiting visas for foreign students, he touches upon many of the reasons why globalization is particularly important to us now at this crossroads in our history. (See also Commission on International Education, 1997; Cornwell \& Stoddard, 1999; Hanson \& Meyerson, 1994.)

\section{Defining Terms}

"Internationalization" is the term that is widely used to refer to four dimensions of American higher education: 1) foreign language study, 2) study abroad, 3) global, diaspora, and area studies, and 4) presence of international students. Additional important dimensions include the presence of international faculty on campus and the involvement of American faculty in teaching and research abroad or with international collaborators (Gaff, Ratcliff, \& Associates, 1997; Hayward, 2000; Mestenhauser \& Ellingboe, 1998). More broadly defined, internationalization refers to efforts to integrate global perspectives and intercultural competencies in higher education.

\section{Goals and Outcomes}

Global competencies are increasingly identified as a valued goal of liberal learning, but currently few American students develop intercultural competence during college. The majority of colleges and universities include the following among their goals for general education: sensitivity to diversity, multicultural and intercultural competencies, and civic, global, and environmental responsibility and engagement (Gaff, 1999; Gaff et al., 1997; Ratcliff, Johnson, La Nasa, \& Gaff, 2001; Schneider \& Shoenberg, 1998). A recent national survey by the American Council on Education indicates very high levels of public support for internationalizing American higher education, with a majority of respondents indicating that students should study abroad and learn foreign languages (Hayward \& Siaya, 2001). Nonetheless, Fred Hayward, author of the Internationalization of U.S. Higher Education: Preliminary Status Report 2000, concludes that "in spite of an apparent growing national interest in international education, relatively few undergraduates gain international or intercultural competence in college" $(2000$, p. 1).

\section{The Evidence}

Res ipsa loquitur, that is, the facts speak for themselves. Foreign language enrollments as a percentage of total higher education enrollments have decreased from $16 \%$ in the 1960 s to $8 \%$ in 2000 . These enrollments are concentrated in a few languages (55\% Spanish, $17 \%$ French, $8 \%$ German, $6 \%$ inclusive of all 
Asian languages, fewer than 2\% Middle Eastern, and .15\% African). This is in sharp contrast to other developed countries where foreign language study is emphasized (Hayward, 2000; Shoenberg \& Turlington, 1998).

Participation in study abroad is equally limited. Despite data from incoming first-year students that they hope to study abroad, only 3\% of American students do study abroad, comprising $0.8 \%$ of total enrollments per year. Students now select shorter programs of study abroad, with the number of students studying for more than a semester abroad falling from $18 \%$ in 1985 to $10 \%$ in 1997 (Hayward, 2000). These shorter experiences reflect numerous factors: more graduation requirements that are more prescribed and sequenced as well as higher costs (Gaff, 1999; Gaff et al., 1997; Ratcliff, Johnson, La Nasa, \& Gaff, 2001). These shorter experiences, while better than nonparticipation, often rely on intercultural shorthand and cultural reductionism that fails to produce intercultural competencies (Cornwell \& Stoddard, 1999; Dobbert, 1998). Nonetheless, these experiences include a broader array of disciplines and different countries than previously. Participants come primarily from majors in the social sciences and humanities-with little ethnic or economic diversity (Hayward, 2000).

The data on international content of courses are more elusive and difficult to assess. Much like data on multiculturalism, it is easier to identify a course designated as a diversity course requirement than it is to identify courses and programs that infuse multicultural content and perspectives throughout the curriculum. Even among courses that infuse global perspectives, there is a significant difference in content and impact between courses and programs that use an additive approach to global content (e.g., adding an international unit or speaker) and those that truly transform the curriculum in substantive ways (Cornwell \& Stoddard, 1999; Mestenhauser \& Ellingboe, 1998). Studies by Davis (1995), Edwards, Jr. (1996) and Klein (1999) summarize trends in interdisciplinary studies in American higher education, indicating that there has been a dramatic increase in interdisciplinary offerings in the last decade, many of which have global dimensions. These include world, global, and international studies; peace and justice studies; ethnic, cultural, diaspora, and area studies; and environmental studies, among others.

Nonetheless, Hayward (2000) concludes that

Broad curricular internationalization is lacking: postsecondary graduates are poorly informed about other countries, people and events; and offerings by institutional type are uneven, with two-year institutions providing far fewer international education opportunities than their four-year counterparts. Competency represents an even more 
pressing concern with one study indicating that less than $7 \%$ of all higher education students meet even basic standards of "global preparedness."... College students consistently perform more poorly on global competency and geography surveys than do students from other developed countries. The authors of a global understanding measure concluded that only a very small proportion of American students command a level of knowledge necessary for even an adequate understanding of global situations and processes. (p. 2)

International students accounted for $3 \%$ of undergraduates and $11 \%$ of graduate students in the Unired States in 1998-1999, more international students than any other country-most of them from Asia (Hayward, 2000). International students provide a vital element in globalizing American campuses, but recent efforts (since September 11, 2001) to ensure tighter controls on visa oversight may reduce the number of international students who will be able to study in the United States in the coming years.

Like the number of international students, the presence of international scholars on American campuses is also on the rise, hosting 70,000 international faculty and researchers in 1998-1999, an increase of $21 \%$ in five years. The majority of these were in the sciences, with $42 \%$ from Asia.

Admission and graduation requirements in foreign language study are an indicator of the importance to which institutions value intercultural competencies. Over the past 30 years, the number of four-year colleges and universities that require a foreign language for admission dropped from $34 \%$ in 1965 to $20 \%$ in 1995 . Among colleges that require a foreign language for graduation, $90 \%$ require a language for humanities majors, $75 \%$ for social science majors, $20 \%$ for business majors, and $17 \%$ for education majors. Only $17 \%$ of institutions have a foreign language graduation requirement for all students.

The number of faculty teaching foreign language is declining nationally. In addition, a 1991 study of projected faculty retirements indicates that "area studies faculty, especially those in Soviet, Eastern European and Asian Studies will not be replaced at self-sustaining rates" (Hayward, 2000, p. 3).

On a more positive note, in the last decade most colleges and universities have designated administrative or faculty support for internationally oriented activities like study abroad and foreign student services (Hayward, 2000). Student affairs professionals and those involved in residential life and the co-curriculum have also actively promoted language study by designing living-learning communities centered around foreign language and cultural themes. 
Over the last decade, federal funding for globalization of American higher education has decreased, including funds for faculty research, educational and cultural exchanges, and language study. There are pockets of support, such as the Department of Education Fulbright-Hays Programs and President Clinton's April 2000 "Memorandum on International Education Policy," identifying the need for university-level internationalization efforts. It is likely that the events of September 11 will lead to increased federal funding, but it is unclear which dimensions of international education will be priorities. It appears that one priority may be foreign language study to prepare graduates for roles in the foreign and diplomatic service, global business, and national security agencies and the military. In the days following the attacks on the Pentagon and World Trade Center, the CIA and other governmental agencies were actively seeking individuals with fluency in Arabic. One radio commentator noted that in 2000 , the United States produced only one graduate with a major in Arabic and prior to September 11, no United States university offered a course in Pashto, the language spoken by half of all Afghans (Shadid, 2002, A4). By February 2002, the United States had committed an additional $\$ 20.5$ million for 2002 , and a proposed $\$ 4$ million more in 2003 , doubling the size of fellowships for study of Arabic, Persian, Pashto, Uzbek, and Urdu. The United States will fund four new academic centers to study Russia, the Middle East, Central Asia, and South Asia. While many academics are celebrating the influx of funds to foreign language and area studies, others are concerned about the role that the Department of Defense will play in campus language programs and tying these programs to national security needs (Shadid, 2002).

Evidence is only anecdotal that the private sector is eager to recruit graduates with intercultural competencies as well as foreign language fluency (Hayward, 2000), but they are often mentioned by multinational corporations as skills that are highly valued among employers.

Hayward (2000) concludes, "The challenge to higher education is clear. We need to increase the participation of students in international programs, reshape and internationalize the curriculum and co-curriculum, and develop a comprehensive international agenda for undergraduates across the curriculum" (p. 4).

\section{What Can Faculty Developers Do to Promote Internationalization?}

Based on the evidence, the picture is sobering, but provocative. The situation can be compared to the dualism of the ancient Chinese symbol for crisis, 
composed of two ideographs-one meaning danger and the other meaning opportunity. The symbol reminds us that inherent within the most difficult challenges there are opportunities for change and growth. As troubling as these reports are, they identify several specific dimensions of internationalization that we can address, and they can serve to provoke both thought and action. What then can faculty developers and campus leaders do to redress these trends?

\section{Where to Begin}

For faculty developers who are new to their campuses or have not had much involvement with globalization on campus, a good place to begin is with a needs assessment developed in collaboration with key stakeholders, including administrators, faculty, students, and those already engaged in international efforts.

Designate an advisory group, steering committee, or task force on globalization. Strategic efforts aimed at systemic change may require participation of a steering committee, advisory group, or task force, at least in its initial stages. Such a group might include campus leaders (administrators and faculty), campus experts in aspects of international education (e.g., study abroad, foreign languages, relevant departments such as area studies, foreign student services, admissions, registrar, multicultural affairs, student affairs, academic advising, etc.), and individuals interested in pursuing a global agenda for the institution. Collectively, they should have the authority and legitimacy to develop and disseminate a needs assessment survey and be empowered to use the data that is collected-either to formulate recommendations or to develop, design, implement, or evaluate them.

Conduct a needs assessment on globalization. As with many campus change initiatives, a needs assessment or faculty development audit on campus globalization may be helpful to clarify the priorities, needs, and current level of activity, interest, and expertise. A needs assessment is the first step in raising levels of awareness and is strategically and politically sound to establish legitimacy for subsequent efforts.

Consider surveying the entire campus community, not only targeted groups such as international faculty or students. It is helpful to collect data from specific groups, but if globalization is intended to be a campus-wide commitment, then all members of the community should be included.

Gather available data on campus globalization. It is helpful to identify and gather the data that is already available about globalization initiatives on campus. This data might include demographic information on international 
faculty and students, including retention data; registration information on study abroad, language study, and courses that feature global content; faculty collaborations with international partners, and funded grants and activities related to international and inter-cultural efforts, among others.

Gather information on resources and best practices from higher education organizations whose missions and expertise include globalization, including for example, the Association of American Colleges and Universities, American Council on Education (ACE), Carnegie Foundation, Kellogg, the Institute of International Education, and NAFSA. Funding agencies like the Fund for the Improvement of Post-Secondary Education (FIPSE), that have long-standing commitments to funding innovations in international education also offer expertise and exemplary models.

In 2000, $A C E$ and the Carnegie Corporation of New York launched a new initiative titled "Promising Practices: Institutional Models of Comprehensive Internationalization," recognizing the achievements of eight institutions that have integrated international activities into their mission, curriculum, and student life. They include Appalachian State University, Beaver College, Dickinson College, Indiana University, Kapi'olani Community College, Missouri Southern State, SUNY Binghamton, and Tidewater Community College (McDonough \& Hayward, 2000). All of these institutions offer benchmarks and best practices (see also Johnston, Jr. \& Edelstein, 1993).

$A$ case in point: $A$ needs assessment of international faculty. Five years ago, in my role as director of faculty development at a large public comprehensive university and with the support of the provost, a colleague and I conducted a needs assessment survey of the international faculty, comprising $10 \%$ of the tenured and tenured track faculty at the institution. The findings revealed widespread and long-standing feelings of marginalization, isolation, and de-legitimization, much like the experiences revealed by American faculty of color and women faculty. There were notable differences between the campus experiences of Asian/Pacific Rim and European faculty and between international faculty trained in the United States and those trained in their countries of origin. Nonetheless, the vast majority expressed disappointment and consternation at their exclusion from the intellectual life of the university. They indicated they were rarely or never invited to share their insights about their cultural heritage with students or their colleagues. Campus-wide panels rarely included their voices or perspectives. As one faculty member wrote, "I've been on this campus for 20 years, and this survey is the first time anyone has asked about my needs or my willingness to share what I know and what I think." Many international faculty expressed anger and frustration at student resistance to their 
instruction, based on what they felt were ethnic biases. Others felt marginalized by colleagues in their departments who excluded them from department decision-making and leadership opportunities and excluded them from discussion in department meetings.

In response to the survey results, the teaching center supported the creation of an international faculty network, providing opportunities for them to socialize and network and to identify areas of common concern, bringing them to the attention of the campus leaders who were empowered to assist them. The needs assessment provided important insights to shape faculty development support and leverage change.

Expand on experiences with diversity and multiculturalism. Build on the efforts and insights of campus initiatives to promote diversity and multicultural education by expanding the goals to include global curricula and intercultural competencies. Cornwell and Stoddard (1999) make the case for integrating efforts to promote diversity and internationalization in higher education, but they note that these movements developed along parallel streams that have not converged in the past, reflecting the history of American isolationism. The process of integrating multiculturalism and internationalization may present significant challenges, but should be worth the effort nonetheless. Broadly defined, diversity learning includes efforts as varied as multicultural curriculum development, inclusive instructional and assessment methods; experiences with diversity in the co-curriculum; and orientation, mentoring, and networking for faculty, particularly persons of color and women, among others. By extension, internationalizing the campus might include the following efforts: curriculum transformation efforts to infuse global perspectives; internationalizing teaching methods, materials, and assessments to address the needs of international students and nonnative speakers; support for international faculty and international graduate teaching assistants through workshops and services to promote English language fluency and knowledge of American cultural norms; networking opportunities for international faculty and students and their families; and venues to enable international faculty and students to share their cultural experiences and perspectives beyond their disciplinary expertise. (See also Achterberg, 2002; Smith, Byrd, Nelson, Barrett, \& Constantinides, 1992.)

A recent study (Humphreys, 2000) on the status of diversity requirements in undergraduate education indicates that $62 \%$ of colleges and universities require a diversity course requirement or plan to do so in the next year. While different curricular models are used, the majority of institutions have a diversity course requirement in which students select one or two courses from a list 
of options. While most of these courses focus on race, ethnicity, gender, class, and sexual orientation in the context of American society, some diversity course options do focus on intercultural issues. While the model of requiring a single diversity course is not a panacea, it has proven to be a productive educational experience that promotes multicultural awareness and competencies. But no single course can carry the full weight of teaching these complex goals. Ideally, these competencies are taught and reinforced throughout the curriculum and co-curriculum.

Similarly, if an additional diversity course requirement on global issues were to be added to the curriculum, it would be important that those skills also be infused throughout the collegiate experience.

One final note on diversity courses: These requirements were adopted at different rates across different regions of the United States (Humphreys, 2000). It can be anticipated that local and regional values will influence the readiness of institutions to embrace requirements for global coursework.

Explore how international education can support other campus initiatives. This might include, for example, service-learning, interdisciplinarity and integrative learning, learning communities, distance learning and other forms of instructional technology, and assessment of student learning outcomes, each of which offers opportunities for international perspectives and experiences.

Increasingly, academic service-learning is being embedded in study abroad programs, such as the program at Worcester Polytechnic Institute in which upper-division students work on group projects under the mentorship of a faculty sponsor to provide service to international communities (Vaz, 2000). Within the United States, many academic service-learning projects take students into local communities in which they can use and develop their intercultural skills and foreign language abilities as they assist communities (DeZure, 2000; Zlotkowski, 2000). As noted above, interdisciplinary studies and learning communities are proliferating, with many of these efforts focusing on international themes and problems of interest worldwide, for example, global warming, AIDS and other global public health issues, and terrorism (DeZure, 1998-1999; Edwards, Jr., 1996; Smith \& McCann, 2001).

And last but not least, instructional technology has enabled cost-effective ways to connect students to the world through online discussions via the Internet with people around the world, both synchronous and asynchronous discussions. One innovative example of distance learning is an engineering course, "Global Product Realization," offered by the University of Michigan in collaboration with the Technical University of Delft and the Seoul National 
University in South Korea. The course involves students and faculty interacting in real time at sites in Korea, the Netherlands, and Michigan. Working in cross-cultural groups called "global product teams," students design, develop, and present products that must be culturally and technically viable in all three countries (Majher \& Kuharevicz, 2001).

Work with student affairs specialists to explore common concerns that might promote dialogue between American and international faculty and students, both in and outside of the classroom (Achterberg, 2002; Dalton, 1999; Hoffa \& Pearson, 1997). The co-curricular dimension of internationalization is very significant and should not be overlooked, particularly in light of the expertise of student affairs staff in providing support to international students and promoting study abroad and other intercultural experiences. Based on Hayward's (2000) data, the majority of campuses now have designated faculty and staff who work with study abroad and other international initiatives, offering campus experience and expertise.

Help faculty integrate international elements in their scholarship. Work with faculty who are pursuing the scholarship of engagement, the scholarship of teaching, and the scholarship of discovery to explore how they might integrate international perspectives in their work. Provide grants to stimulate interest and bring grantees together to share their efforts and to develop a network of faculty engaged in global activities.

\section{Expanding and Maximizing Current Efforts}

Many faculty developers are already actively engaged in supporting one or more aspects of internationalization on their campuses. Many developers were directly involved in responding to campus needs immediately following the World Trade Center disaster. They developed and disseminated guidelines for classroom and campus discussions about the event; they sponsored discussions and teach-ins; and they endeavored to support international faculty, students, and staff lest they become targets of misguided frustration and anger (Cook, 2001; Ehrlich, 2001; Kardia, Bierwert, Cook, Miller, \& Kaplan, 2002).

Prior to September 11, many faculty developers were already active in many aspects of internationalization. These include 1) support for international faculty through orientation sessions, workshops, and networking groups, 2) support for international graduate student teaching assistants, 3) support for all faculty through workshops on the instructional needs of international students and more generally on how to ensure an inclusive and culturally sensitive learning environment, and 4) curricular planning to integrate 
global perspectives, content, and skills for faculty teaching in the United States and abroad, among others.

For developers already actively involved in internationalizing their campuses, the question is not where should I begin, but what more can I do and how can I do it more effectively?

Integrate and aggregate efforts. One option is to identify the range of campus activities already in place and to make them more visible and integrated, enabling them to function synergistically. The sum can be greater than its parts. All too often faculty development efforts occur as isolated activities, known only to participants and their direct sponsors. When packaged and promoted in the aggregate, they are more likely to create the critical mass of activity and momentum that will foster institutional recognition and commitment (DeZure, 2000).

Assess the impact. A second option is to focus on assessment of the global initiatives on your campus to determine their impact on participants and on the campus culture more broadly. While many schools now identify global and intercultural competence as a learning outcome for general education and the collegiate experience, very few institutions have assessed whether their students attain those goals.

Build cross-institutional collaborations. A third option for faculty developers who have well-developed global initiatives is to seek out and participate in cross-institutional and cross-organizational collaborations, often with external funding.

Combine initiatives in creative ways. A fourth option is to combine campus initiatives in novel ways. Much of the cutting-edge work in global education involves new combinations of instructional innovations. These include, for example, the integration of academic service-learning with study abroad, learning communities focused on global themes, or the use of instructional technology and distance learning to engage students around the world in problem-based learning. The Global Intercultural Experiences Program at the University of Michigan provides undergraduate work-study students with opportunities to do research with faculty abroad. Participating faculty receive grants to support their research and participating students receive stipends. This model addresses one of the long-standing challenges of study abroad to increase the ethnic and economic diversity of participants.

\section{Conclusion}

Faculty development is a field charged with maintaining the delicate balance between leadership and service. We have a leadership role in shaping the vision 
for teaching and learning on our campuses. We do that by keeping our eyes on the national and international educational horizons for innovations and winds of change, by keeping abreast of best practices and what research has to tell us about effective teaching and learning, and by sharing these with our campuses. But we are also charged with providing service and being field-responsive to our campus and its varied constituencies. We do that by assessing campus needs; anticipating what it will take to promote and support change within the institutional context; providing training and development when needed; and putting into place those structures, opportunities, and rewards that will enable faculty and administrators to engage in change and to succeed. We have to calibrate the larger vision with the campus realities. Internationalizing higher education is one of those larger visions worthy of our time, efforts, and expertise as change agents. To reiterate the words of President McPherson (2001): "International Education. Now More Than Ever" (p. A30). It is more than a media sound bite. It is a call to thought and action.

\section{REFERENCES}

Achterberg, C. (2002). Providing a global perspective. About Campus, 6(6), 17-24.

Commission on International Education. (1997). Educating for global competence: America's passport to the future. Washington, DC: American Council on Education.

Cook, C. E. (2001, November 18). Center gives teachers guidelines for discussing terrorism. Ann Arbor News, p. B2.

Cornwell, G. H., \& Stoddard, E. W. (1999). Globalizing knowledge: Connecting international and intercultural studies. Washington, DC: Association of American Colleges and Universities.

Dalton, J. C. (1999). Beyond borders: How international developments are changing student affairs practice. New Directions for Student Services, No. 86. San Francisco, CA: Jossey-Bass.

Davis, J. R. (1995). Interdisciplinary courses and team teaching: New arrangements for learning. Phoenix, AZ: American Council on Education/Oryx Press.

DeZure, D. (1998-1999). Interdisciplinary teaching and learning. Teaching Excellence Essays: Toward the Best in the Academy, 10 (3). Stillwater, OK: Professional and Organizational Development Network in Higher Education.

DeZure, D. (Ed.). (2000). Learning from Change: Landmarks in teaching and learning in higher education from Change magazine (1969-1999). Sterling, VA: Stylus. 
Dobbert, M. L. L. (1998). The impossibility of internationalizing students by adding materials to courses. In J. A. Mestenhauser \& B. J. Ellingboe (Eds.), Reforming the higher education curriculum: Internationalizing the campus (pp. 53-68). Phoenix, AZ: American Council on Education/Oryx Press.

Edwards, A. F., Jr. (1996). Interdisciplinary undergraduate programs: A directory (2nd ed.). Acton, MA: Copley.

Ehrlich, C. (2001, November 9). Engineers evaluate their responsibilities. The Michigan Daily, p. 3.

Gaff, J. G. (1999). General education: The changing agenda. Washington, DC: Association of American Colleges and Universities.

Gaff, J. G., Ratcliff, J. L., \& Associates. (1997). Handbook of the undergraduate curriculum: $A$ comprehensive guide to purposes, structures, practices and change. San Francisco, CA: Jossey-Bass.

Hanson, K. H., \& Meyerson, J. W. (1994). International challenges to American colleges and universities: Looking ahead. Washington, DC: American Council on Education/Oryx Press.

Hayward, F. M. (2000). Internationalization of U.S. higher education: Preliminary status report 2000. Washington, DC: American Council on Education.

Hayward, F. M., \& Siaya, L. M. (2001). Public experience, attitudes, and knowledge: A report of two national surveys about international education. Washington, DC: American Council on Education.

Hoffa, W., \& Pearson, J. (1997). NAFSA's guide to education abroad for advisers and administrators. Washington, DC: NAFSA Association of International Educators.

Humphreys, D. (2000). National survey finds diversity requirements common around the country. Diversity Digest. Retrieved from http://www.diversity web.org/Digest/f00/survey.html

Institute of International Education. (2000). Open doors 2000. New York, NY: Institute of International Education.

Johnston, J. S., Jr., \& Edelstein, R. J. (1993). Beyond borders: Profiles in international education. Washington, DC: Association of American Colleges and Universities.

Kardia, D., Bierwert, C., Cook, C. E., Miller, A. T., \& Kaplan, M. L. (2002, February/January). Discussing the unfathomable: Classroom-based responses to tragedy. Change, 34(1), 18-23.

Klein, J. T. (1999). Mapping interdisciplinary studies. Washington, DC: Association of American Colleges and Universities. 
Majher, P., \& Kuharevicz, N. L. (2001, January 15). Engineering's innovative global product development course taught simultaneously on three continents. The University Record, 1-2. McDonough, T., \& Hayward, F. (2000, October 20). ACE, Carnegie select eight institutions with outstanding international programs. $A C E N e w s$. Retrieved from htrp://www.acenet.edu/news/press_release/2000/10 october/carnegie.html

McPherson, M. (2001, December 9). International education. Now more than ever. New York Times, p. A30.

Mestenhauser, J. A., \& Ellingboe, B. (1998). Reforming the higher education curriculum: Internationalizing the curriculum. Phoenix, AZ: American Council on Education/Oryx Press.

Ratcliff, J. L., Johnson, L. D., La Nasa, S. M., \& Gaff, J. G. (2001). The status of general education in the year 2000: Summary of a national survey. Washington, DC: Association of American Colleges and Universities.

Schneider, C. G., \& Shoenberg, R. (1998). Contemporary understandings of liberal education. Washington, DC: Association of American Colleges and Universities.

Shadid, A. (2002, February 26). 'Arc of crisis' study funds hiked: U.S. adding language training centers for strategically important areas. Ann Arbor News, p. A4.

Shoenberg, R. E., \& Turlington, B. (1998). Next steps for languages across the curriculum: Prospects, problems, and promise. Phoenix, AZ: American Council on Education/Oryx Press.

Smith, B. L., \& McCann, J. (2001). Reinventing ourselves: Interdisciplinary education, collaborative learning, and experimentation in higher education. Bolton, MA: Anker.

Smith, R. M., Byrd, P., Nelson, G. L., Barrett, R. P., \& Constantinides, J. C. (1992). Crossing pedagogical oceans: International teaching assistants in U.S. undergraduate education. ASHE-ERIC Research Reports, Vol. 21, No. 8. Washington DC: ERIC Clearinghouse on Higher Education.

Vaz, R. F. (2000). Connected learning: Interdisciplinary projects in international settings. Liberal Education, 86(1), 2-9.

Zlotkowski, E. (1997-2000). AAHE series on service-learning in the disciplines. Washington, DC: American Association for Higher Education.

Contact:

Deborah DeZure

Coordinator of Faculty Programs

Center for Research on Learning and Teaching (CRLT) 
University of Michigan

3300 SEB

610 East University Street

Ann Arbor, MI 48109-1259

Voice (734) 936-1135

Fax (734) 647-3600

Email ddezure@umich.edu

Deborah DeZure is Coordinator of Faculty Programs at the Center for Research on Learning and Teaching (CRLT) at the University of Michigan. Deborah edited Learning from Change: Landmarks in Teaching and Learning from Change Magazine (1969-1999) (2000, Stylus Publications in collaboration with AAHE) and To Improve the Academy (1997) and published numerous book chapters and articles in journals such as Academe, Change, AAHE Bulletin, Thought and Action, and publications of the NCTE. Deborah is a Contributing Editor of Change and serves on the editorial boards of Journal of Excellence in College Teaching, Issues and Inquiry in College Teaching, Issues in Interdisciplinary Studies, and the Michigan Journal of Community Service Learning. She is also chair of the POD National Outreach Sub-committee. Previously, Deborah was Director of the Faculty Center for Instructional Excellence at Eastern Michigan University, where she was also Education Consultant to the President. 